\title{
Magnetic surveys locate Late Bronze Age corrals
}

\author{
Tatiana Smekalova $^{1,2} \odot$ | Bruce Bevan ${ }^{3} \odot \quad \mid$ Maya Kashuba ${ }^{4} \quad$ Fedor Lisetskii ${ }^{5} \odot$ | \\ Alexander Borisov $^{6}$ | Natalia Kashirskaya ${ }^{6}$
}

\author{
${ }^{1}$ Department of Natural Sciences in \\ Archaeology, Crimean Federal University, \\ Simferopol, Russia \\ ${ }^{2}$ National Research Center, Kurchatov \\ Institute, Moscow, Russia \\ ${ }^{3}$ Geosight, Weems, VA, USA \\ ${ }^{4}$ Institute of the History of Material Culture of \\ the Russian Academy of Sciences, St \\ Petersburg, Russia \\ ${ }^{5}$ Belgorod State National Research University, \\ Belgorod, Russia \\ 'Laboratory of Archaeological Soil Science, \\ Institute of Physical-Chemical and Biological \\ Problems of Soil Science, Russian Academy of \\ Sciences, Pushchino, Russia

\section{Correspondence} \\ Tatiana Smekalova, Department of Natural \\ Sciences in Archaeology, Crimean Federal \\ University, Simferopol 295007, Russia. \\ Email: tnsmek@mail.ru \\ Funding information \\ Russian Foundation for Basic Research, Grant/ \\ Award Number: project number 18-00-00563 \\ K (18-00-00486)
}

\begin{abstract}
A new type of livestock enclosure from the Late Bronze Age has been discovered. Stone walls outline a pair of circular or oval areas that may be up to $50 \mathrm{~m}$ in diameter. The stone walls are invisible at the surface; they were discovered in north-western Crimea and only with the aid of remote sensing and geophysical surveys. In the period 2007-2020, over two dozen of these structures were found; none has ever been noted before. The locations of these sites were first suggested in satellite imagery, often as areas with unusually green vegetation. Then, large-area magnetic surveys delineated the buried stone enclosures, for there was a good contrast between the non-magnetic limestone walls and the rather magnetic soil. The features can be identified by the unique pattern of the walls: An almost-complete circular arc that is connected to a full circle or oval. The soil within the features has a high level of urease enzyme activity and a high concentration of thermophilic microorganisms. This suggests the composting of animal dung and plant residues; therefore, these were corrals and the raising of livestock was a part of the economy. Only one of the doubled enclosures is found at most settlements; the livestock were probably owned by all of the inhabitants. Each settlement had several dwellings, and these had earthen basins whose edges were lined with vertical stone slabs. Several small-area excavations exposed corral walls. Magnetic measurements of the soil and rock were the basis for magnetic models; the calculated anomalies agree with the measurements of the magnetic maps.
\end{abstract}

\section{KEYWORDS}

corral, Crimea, Late Bronze Age, livestock, magnetic survey

\section{1 | INTRODUCTION}

In the Late Bronze Age (fifteenth-tenth centuries Bc), north-western Crimea was inhabited by settled tribes who farmed and raised livestock. These tribes belonged to the Sabatinovka and Belozerka cultures. Their sites have been investigated by Vitaliy A. Kolotukhin (Колотухин, 2003); he compiled a map of their distribution and excavated several sites on the north-western coast of the Tarkhankut peninsula: The settlements of Burun-Eli (second half of the fourteenth century Bc), Skalistoye-2, Vodopoynoye-1, and Bay-Kiyat (twelftheleventh centuries BC) (Figure 1, sites 2-5). Kolotukhin's excavations revealed as many as ten dwellings in each settlement. These dwellings were found to be shallow rectangular pits with their walls faced with flat stone slabs that had been set on edge. The lengths of the pits or basins ranged from 4 to $8 \mathrm{~m}$. Fireplaces, ash pits, and several other domestic pits were found in each building. In addition, a line of pits marked where pillars once supported a roof.

The new research that is described here was carried out in 2007-2020. It continues Kolotukin's work with the discovery of new settlements; most importantly, we have now found livestock corrals at many settlements. The four phases of this work were: Analysis of satellite photographs, field walking, performing magnetic and 


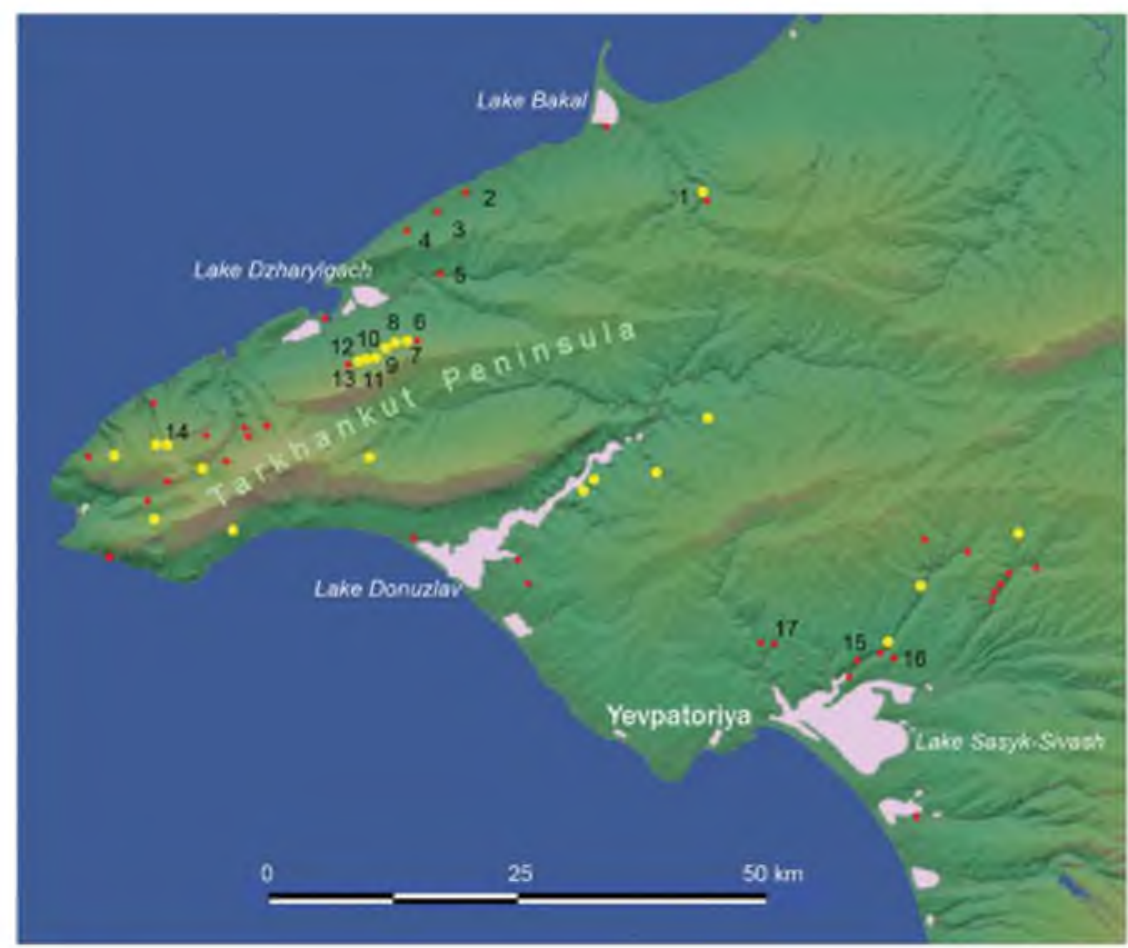

FIGURE 1 A shaded relief map of northwestern Crimea. Yellow circles locate Late Bronze Age sites that have corrals. Red circles mark those sites that are without corrals, or where none are known. The numbers identify sites that are discussed in this article: 1 , Bakal2; 2, Burun-Eli; 3, Bai-Kiyat; 4, Skalistoye-2; 5, Vodopoinoye- $1 ; 6, \mathrm{H} 14 ; 7, \mathrm{H} 20 ; 8, \mathrm{H} 8$; 9, H9; 10, H6; 11, H2; 12, H1; 13, Snezhnoe; 14, H22a; 15 , Tyumen $15 ; 16$, Tyumen 3 ; 17 , Bagai [Colour figure can be viewed at wileyonlinelibrary.com]

conductivity surveys, and making some small excavations. We have discovered 45 new settlements of the Late Bronze Age and 22 of them have double corrals; together with Kolotukin's discoveries, there are now 61 known sites in north-western Crimea (Figure 1). These discoveries have allowed an evaluation of the economy and social structure of the local population in the Late Bronze Age (Смекалова, 2010; Смекалова \& Кутайсов, 2017).

\section{I PRIOR EXPLORATIONS AT RELATED SITES}

Other researchers have found that aerial photography can provide detailed evidence of ancient farming, and LiDAR (light detection and ranging) maps have recently become very helpful. However, old fields may now be buried under a layer of deposited soil; geophysical exploration may be needed then. Chadwick (2013) has summarized the detection of ancient fields in England with geophysical methods. A magnetic survey in Greece delineated canals and dikes that could mark field boundaries (Lane, Horsley, Charami, \& Bittner, 2016), while another magnetic survey in Italy detected possible pits for a rural Greek farmhouse (Davis, Prieto, Lovén, \& Christiensen, 2003). In Crimea, several Greek farmhouses and vineyards have been revealed with a magnetometer (Smekalova, Bevan, Chudin, \& Garipov, 2016) Techniques for detecting prehistoric fields in the United States have been summarized by Nolan (2014); he indicates that measurements of magnetic susceptibility are suitable for revealing gardens where native vegetation has been burned to allow farming.

Magnetic surveys have been made at many Bronze Age sites in Europe. These have found many fascinating anomalies: A city plan in
Turkey (Matney \& Algaze, 1995), a fortified settlement in Russia (Martyshko, Noskewich, Fedorova, \& Muraviev, 2010), enclosures of concentric circles in Poland (Furmanek, Mackiewicz, Myślecki, \& Wroniecki, 2015), fortresses in Armenia (Lindsay, Leon, Smith, \& Wiktorowicz, 2014), and tells in Hungary (Fischl, Kienlin, \& Pusztai, 2016). About 300 stone monuments, dating to about $1000 \mathrm{BC}$, have been discovered with magnetic surveys in the North Caucasus (Reinhold, Korobov, \& Belinskij, 2017, 213-245, figures $150,167)$. The compilation of magnetic maps by Becker and Fassbinder (2001) includes additional illustrations from many sites. However, neither these nor any other publication of geophysical maps, aerial photographs, or site maps has been found that shows the pattern of the corrals that has been revealed by this exploration.

Only a few geophysical surveys have found reliable evidence of either a corral or other livestock enclosures. In Kazakstan, rather circular alignments of magnetic anomalies (possibly post holes) could outline horse corrals (Olsen, Bradley, Maki, \& Outram, 2006, 106). Oval magnetic features in Armenia coincide with visible rings of stones; these might reveal corrals from the Bronze Age or recent times (Lindsay, Smith, \& Badalyan, 2010). In the western United States, magnetic susceptibility surveys at an 1840 fort have found high readings at the location of a known corral (Wiewel \& Kvamme, 2014, 14). Two mud walls of a corral at another historic fort in the United States were detected by a magnetic survey; this anomaly could be identified because of an historic map and notes (De Vore, 2002). A former stable at the historical site of Harpers Ferry in the United States was detected as a region of low resistivity (Bevan, 1996); the locations of corrals along the nineteenth century stage stop in the western United States have also been found to have low resistivity. Modern corrals and livestock feedlots have been investigated with resistivity 
and conductivity surveys; this is because they may be a source of water pollution.

\section{3 | LANDSCAPE CHARACTERISTICS OF THE SETTLEMENTS}

Each settlement of the Late Bronze Age in north-western Crimea occupies a distinctive niche in the landscape: It is situated on a promontory, or ridge, between two converging ravines or on the side of a ravine (Смекалова \& Кутайсов, 2017, 93, 94). People and livestock were protected from cold winds when they descended to the bottoms of the nearby ravines in the cold part of the year; this was most important in late winter or early spring when domestic animals gave birth. There is also a hydrological advantage, for the water-bearing horizon is shallower near the bottom of valleys; a well there does not need to be very deep. Additionally, dams were constructed in the ravines for storing meltwater during winter and springtime.

Settlements from the Late Bronze Age are often revealed by a thick humus-enriched soil that is visible on eroded surfaces and on soil mounds at the burrows of rodents and foxes. This soil has an ashy colour and it contains many fragments of animal bones and handmade pottery. The animal burrows themselves are good indicators of settlements. Another indicator is thick vegetation, usually dominated by cotton thistle (Onopordum acanthium), wild onion, wormwood, and wild flax. All of these natural signs were sought during surface surveys (Смекалова, 2010).

A temporal model of the formation of soil humus has been developed for the Crimean steppe (Lisetskii, Smekalova, \& Marinina, 2016). This shows that the humic horizon at settlements of the Late Bronze Age has a thickness of $52 \mathrm{~cm}$ in the sixteenth-fourteenth centuries $\mathrm{BC}$; during two later periods (thirteenth-twelfth and eleventh-ninth centuries $\mathrm{BC}$ ), this thickness is $46-49 \mathrm{~cm}$. If the cultivated soil at the settlements is a clay loam with little gravel, modern steppe vegetation can form a soil layer that can even be thicker than these ancient buried soils.

\section{4 | THE GEOPHYSICAL CHARACTER OF THESE SITES}

Bedrock at all of these sites is porous and layered limestone; the soil has been derived primarily from that limestone and it has a high content of clay. The soil contains a moderate fraction of stones. These are often about $0.1 \mathrm{~m}$ in diameter, although large stones with a diameter of up to $0.5 \mathrm{~m}$ can be found at the surface. Limestone bedrock is visible on the sides of some ravines; in most other areas, it may be at a depth of about $1 \mathrm{~m}$.

The parameter called volume magnetic susceptibility is identified here as 'parts per thousand', and abbreviated ppt. This parameter can be converted to the common value for susceptibility, which has no unit name, by simply dividing by 1000 . Therefore, a susceptibility of $1 \mathrm{ppt}$ is the same as $0.001 \mathrm{SI}$.
Limestone is almost non-magnetic, for its susceptibility at these sites is typically $0.01 \mathrm{ppt}$ (the same as $1 \times 10^{-5} \mathrm{SI}$ ). The soil is moderately magnetic and its susceptibility is about $1 \mathrm{ppt}$. The remanent magnetization of the soil was found to be $20-40 \%$ of its induced magnetization. This was determined by cutting four different samples of soil into approximate spheres; they were then rotated near the sensor of a magnetometer. The procedure is described in Bevan (2016, appendix 4). The origin of this remanent magnetization has not been investigated. The electrical conductivity of the soil is usually 10-20 $\mathrm{mS} / \mathrm{m}$, while the conductivity of bedrock is less than $5 \mathrm{mS} / \mathrm{m}$.

At these sites, the magnitude of the Earth's magnetic field was about $49500 \mathrm{nT}$ at an inclination of $63^{\circ}$. Magnetic north was about $7^{\circ}$ east of geographic north in this area.

These geophysical surveys were performed in rural areas with typical steppe vegetation. Native grass can reach a height of $1 \mathrm{~m}$, but it dies off in the winter. There are a few small bushes, but no trees within the areas of work. While the surveys were usually near ravines, the areas of exploration were often rather flat.

\section{5 | THE METHOD OF INVESTIGATION}

The search for settlements was accomplished with remote sensing, geophysical exploration, and traditional archaeology. At first, satellite photographs of large areas were examined and interpreted. Images from Google Earth were suitable, and these photographs are included in the figures here. The settlements of the Late Bronze Age are most apparent in photographs that were taken in spring. During this time there is a good contrast in uncultivated vegetation, and corrals are often found at green spots. This is because of the dense vegetation that grows in the fertile soil within the corals and near the settlements. In fields that are currently plowed, the ashy colour of the soil is visible.

Promising locations were selected, their geographic coordinates were noted and routes for at-surface surveys were mapped. Next, motorcar and pedestrian examination was conducted in order to check the areas. Identification of settlements dating to the Late Bronze Age is complicated by the fact that the stone structures are now buried and invisible at the surface. The same clues that applied to the interpretation of satellite photographs aided an examination on the ground; diagnostic potsherds may allow the dating of settlements to the Late Bronze Age.

The final and best evidence of a settlement from the Late Bronze Age was obtained through magnetic surveys (Aspinall, Gaffney, \& Schmidt, 2008; Smekalova et al., 2016); these surveys revealed the unique patterns of the double pens and also the cluster of dwellings that are often nearby. These magnetic maps were the basis for locating excavations.

The geophysical instrument was an Overhauser four-sensor magnetometer, a model GSM-19WG from the Canadian company, Gem Systems. This instrument measured the total magnetic field of the Earth. The four sensors were mounted on a wheeled cart and this allowed a strip that was $2 \mathrm{~m}$ wide to be measured during each 
traverse (Figure 2). The active centres of the sensors were at a height of about $0.3 \mathrm{~m}$ above the ground surface. A separate base station magnetometer provided a temporal correction for the magnetic maps.

After this temporal correction, the magnetic maps needed no further data processing, except for the site of Tyumin 15. A malfunction of the magnetometer caused errors spikes at $0.4 \%$ of the measurements during the survey of that area; most of these errors have either been deleted or replaced by the median of the eight adjacent readings.

In the resulting grey-scale magnetic maps, positive anomalies (magnetic highs) are shown as dark grey, while light grey marks negative anomalies. These negative anomalies outline a double pen in Figure 3; the anomalies are primarily negative because the stone of the pens is less magnetic than the surrounding soil.

The calculated anomaly in Figure 4 is similar to the pattern found in the magnetic measurements of stone corrals. As suggested by this calculation, the magnetic high in Figure 3 is weaker on the east and west sides of the corral. The calculations were made with the Potent (for Potential field) program from Geophysical Software Solutions.

The Potent program is usually applied to the automatic determination of a magnetic model whose calculated field is most similar to one's measurements. This is called a magnetic inversion. For the analyses here, the program was operated in its forward modelling mode; the magnetic models were manually changed until good matches were found between the calculations and the measurements. Forward modelling was applied because the magnetic maps at these sites have significant spatial noise caused by random stones in the soil; inversion is affected too strongly by this variability. Forward modelling also allows constraints between different parts of a magnetic model, such as their relative locations or directions of magnetization; these constraints are not available with inversion software that is now available.

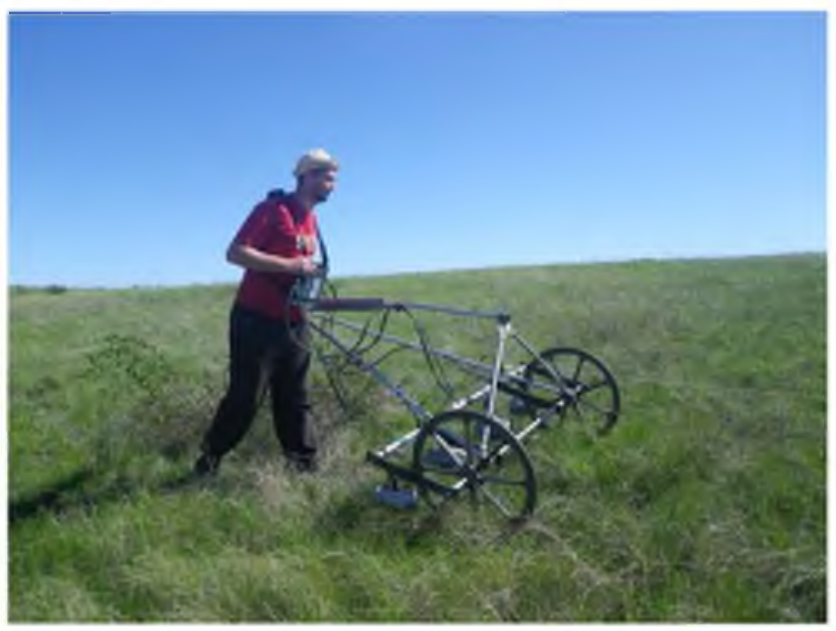

FIGURE 2 The Overhauser magnetometer with its four sensors on a cart. The sensors are the white cylinders along the bar; the control-readout unit is carried in front of the operator. Typical steppe vegetation is seen here [Colour figure can be viewed at wileyonlinelibrary.com]

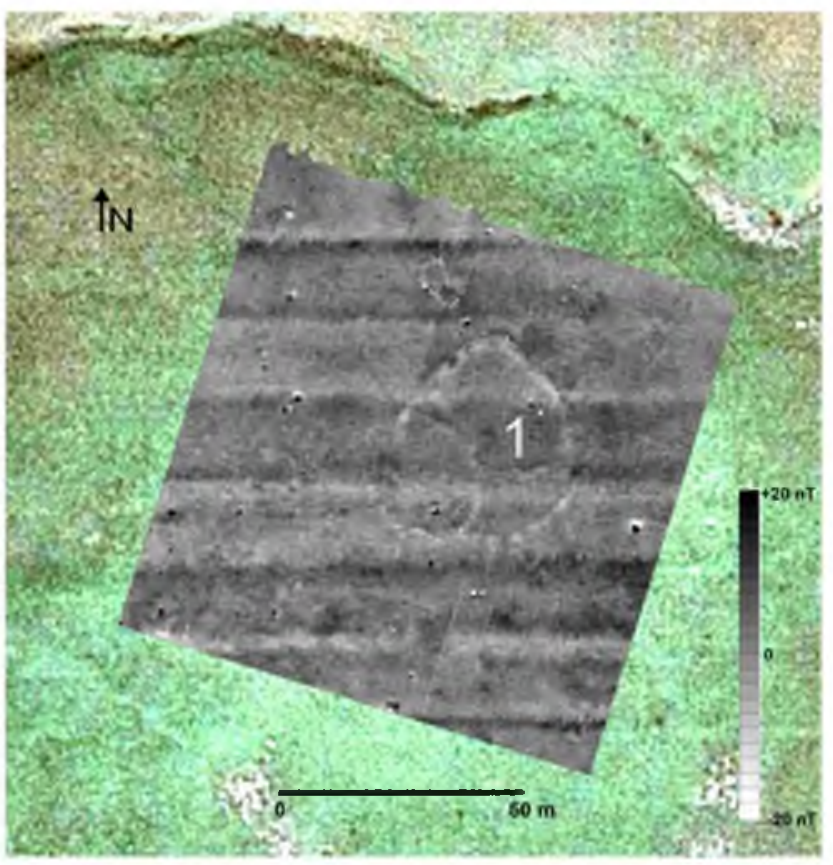

FIGURE 3 A double corral at site $\mathrm{H} 6$. This is a grey-scale magnetic map; the large arc-shaped corral is marked 1 . The walls of this corral connect to a smaller corral on the left. The buried stone walls are revealed as a light grey line, for the stone is less magnetic than the soil. The background here is a satellite image; the green colour reveals the lush vegetation around this Late Bronze Age settlement. The fertile soil attracted later people; they plowed the fields that are seen here as horizontal stripes. This site is on the slopes to the south of Lake Dzharylgach (see site 10 in Figure 1) [Colour figure can be viewed at wileyonlinelibrary.com]

These Bronze Age sites have been explored primarily with magnetometers. However, some additional information was acquired from conductivity surveys with a Geonics model EM38RT electromagnetic induction meter. The stone walls of the corrals appear to be invisible to the conductivity survey; however, the conductivity meter sometimes, but not always, found high conductivity within the corrals. Some of the house pits were detected as high-conductivity anomalies. Other high conductivity anomalies were also revealed; these are likely to have a cultural origin, although their true source has not yet been revealed by excavation.

The parameters of electrical conductivity and magnetic susceptibility are independent of each other for many archaeological features; it is valuable to record both. While the EM38 can also measure the magnetic susceptibility of the soil, that mode has not been applied since those findings would be similar to those of the magnetometer. However, if the stones had remanent magnetization, a magnetic susceptibility survey would have yielded simpler maps. For further information on the archaeological applications of the EM38, see the monograph by Clay (2000).

For the conductivity surveys, the magnetic dipoles of the EM38 were vertical and the base of the instrument was at a height of about $0.2 \mathrm{~m}$ above the soil; the measurements have not been corrected for this height. Readings were made at intervals of $0.5 \mathrm{~m}$ along lines of 
FIGURE 4 The magnetic anomaly of a circular ring. This calculated magnetic map approximates the anomaly of a stone circle. The magnetic low above the ring changes little around the circumference. However, the magnetic high to the north of the ring changes around the circumference; it is lowest on the east and west sides of the ring [Colour figure can be viewed at wileyonlinelibrary.com]

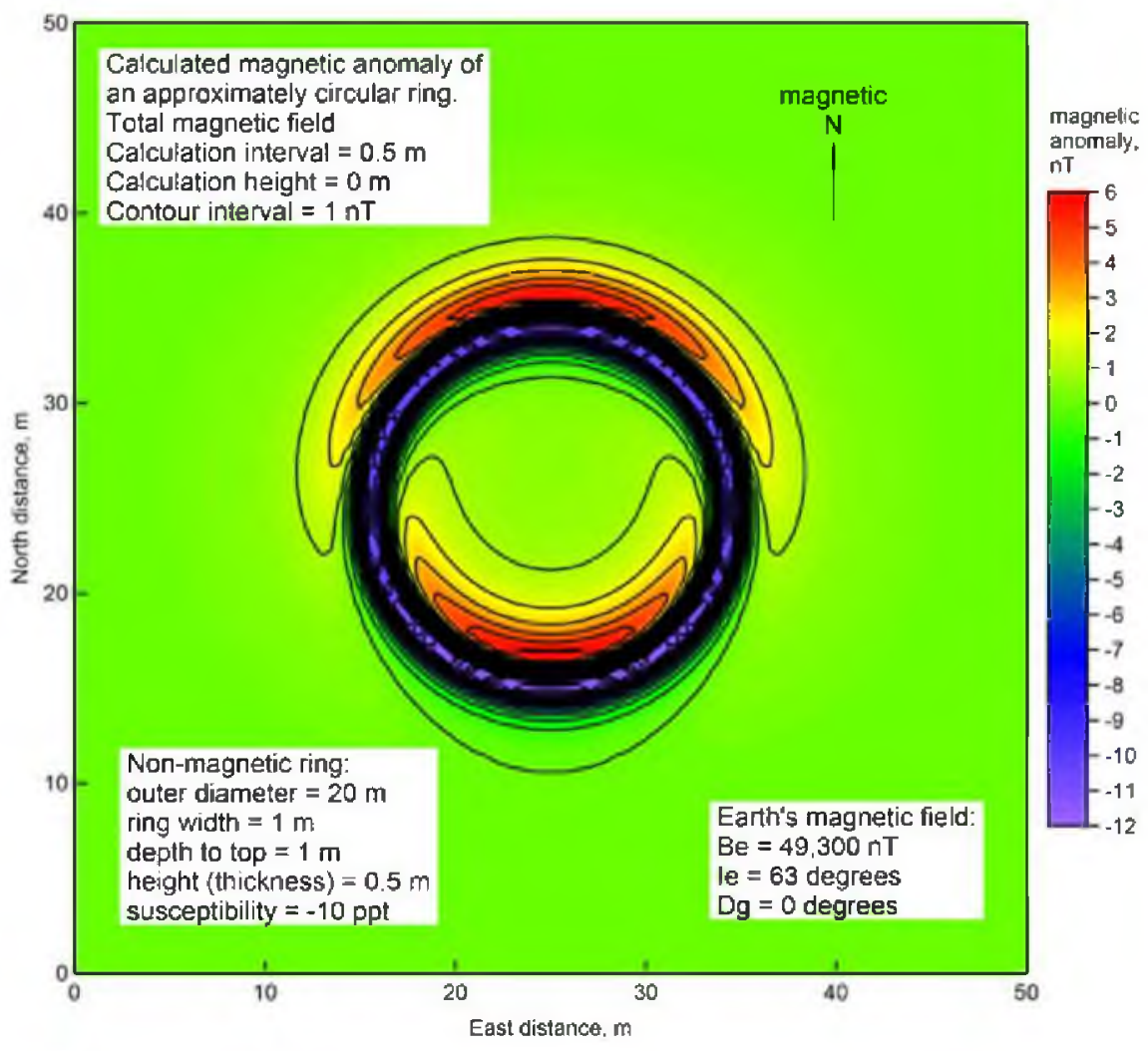

traverse that were spaced by $0.5 \mathrm{~m}$. It was necessary to shift the locations of the readings backwards along each traverse by a distance of $0.75 \mathrm{~m}$; this corrected for a measurement delay and averaging that is always found with fast surveys.

\section{6 | RESULTS OF THE GEOPHYSICAL SURVEYS}

The most remarkable discoveries are the pairs of large stone-walled animal pens (corrals) at many of the settlements of the Late Bronze Age. The magnetic surveys in north-western Crimea have now revealed over 20 locations with double pens. Most of the corrals have a similar shape: They have a rather small and round circle that is 20-23 $\mathrm{m}$ in diameter and a larger oval-shaped arc that connects to the small circle. This is somewhat like the pattern of the letters Co. The total diameter of the pair of corrals is $45-50 \mathrm{~m}$. The stone walls of the smaller circle are usually narrower than the walls of the larger arc-shaped corral. Breaks are found in the magnetic anomaly of some of the curvilinear walls; these may be entrances. The discovery of these corrals is a new result for the Late Bronze Age in Crimea. They have remained undiscovered until now because of their large open areas and because they are covered with topsoil. They have been revealed only with the analysis of satellite images, followed by magnetic surveys.

The northernmost example of a double pen was found at the settlement called Bakal 2, which is located between two ravines that end at Lake Bakal (Figure 1, site 1). At this settlement, magnetic surveys revealed a stone-walled double pen; the largest is $48 \mathrm{~m}$ wide and the smaller one has a diameter of $17 \mathrm{~m}$.

A soil section inside a corral at this site was investigated (Lisetskii et al., 2016). The soil at the depth of the wall had an unusual ashy colour and it contained small fragments of animal bones and handmade pottery dating to the Late Bronze Age. Similar soil has been observed both in excavations and at the surface at other sites that have double pens from the Late Bronze Age; however, this was the first site where a detailed study was applied.

Microbiological analyses of the soil from the same layer were also made. These suggested that the ashy colour of the soil was probably not caused by burning wood; instead, it was a result of the composting of some plant material. Both processes create similar soils: The colour turns whitish and the soil becomes powdery and structureless.

When plants are burned, charcoal is always created; the composting of plant residues does not produce charcoal. However, the composting of animal dung or plant residues causes heating; as a result, thermophilic microorganisms develop and these can remain in the soil for an indefinitely long time. A large number of thermophilic microorganisms can be an indicator of the accumulation and composting of animal dung at archaeological sites (Chernysheva, Korobov, \& Borisov, 2017).

The soil at this site was analyzed at six different depths; see Figure 5. The soil sample from the depth of the stone wall $(35 \mathrm{~cm})$ had no charcoal; instead, it contained a large number of thermophilic microorganisms (260 000 cells per gram). These microorganisms grow at a temperature of about 60 to $70{ }^{\circ} \mathrm{C}$; they are not found in soils 


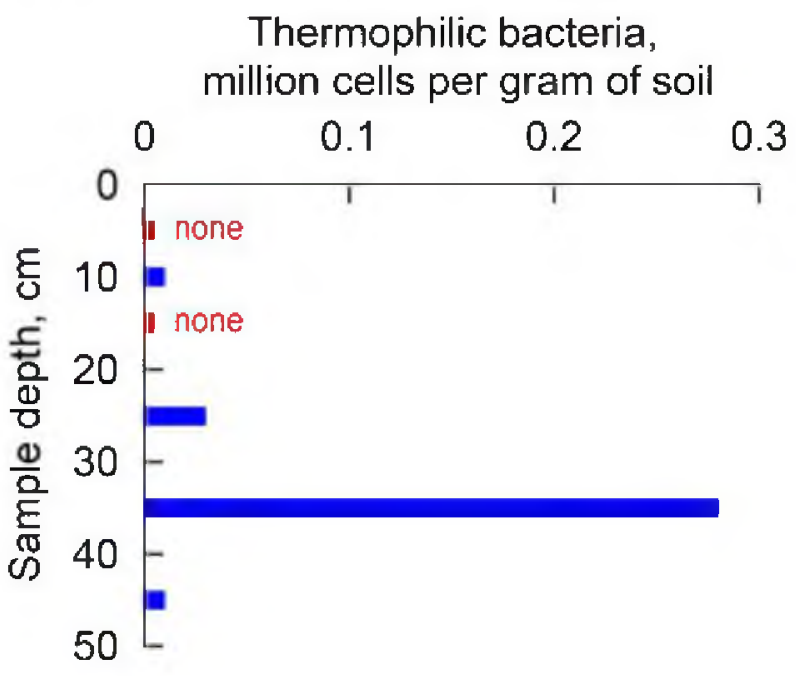

FIGURE 5 The number of thermophilic bacteria within soil samples from the side of an excavation at the Bakal 2 site. These samples were taken inside the stone enclosure, which was at a depth of about $35 \mathrm{~cm}$. The high number of bacteria at that depth implies the composting of manure and other vegetation. Therefore, this can be interpreted as an ancient corral [Colour figure can be viewed at wileyonlinelibrary.com]

except where plant material is composting. There is no other reason for the appearance of thermophilic microorganisms in soils. Therefore, there was an accumulation of animal dung from the livestock in the corrals; this was heated during composting, creating the large number of thermophilic microorganisms. The high level of urease enzyme activity in the soil also confirms the presence of animal dung. At the depth of $40 \mathrm{~cm}$ the urease activity rose to $400-500 \mu \mathrm{g} \mathrm{NH}_{4}{ }^{+} / \mathrm{g}$ of soil/h. In undisturbed steppe soils the urease activity is less then 200-400 $\mu \mathrm{g} \mathrm{NH}_{4}{ }^{+} / \mathrm{g}$ of soil/h (Chernysheva, Korobov, Khomutova, $\&$ Borisov, 2015)

Thus, we have additional confirmation that the stone walls enclosed animal pens, which further suggests that the tribes of the Late Bronze Age raised livestock.

\section{1 | Settlements with corrals}

The largest number of double pens (18) have been discovered on the Tarkhankut peninsula, see Figure 1. Eight settlements from the Late Bronze Age have been discovered on the slopes near Lake Dzharylgach (Figure 1, sites 6-13). The magnetic surveys identified seven animal pens as double-ovals (one settlement had no corral); additionally, earthen dwelling houses were found at four of these settlements. It is remarkable that the corrals at these sites are very similar in size and shape. All of them have a small round corral and a larger oval-shaped corral. Settlement $\mathrm{H} 8$ is typical and its double pen is about $150 \mathrm{~m}$ from the associated dwellings (Figure 6).

An archaeological excavation exposed a small part of the corral wall at site $\mathrm{H} 8$ (see the red arrow in Figure 6). Figure 7 is a photograph of the wall in that excavation. The wall has a vertical thickness of

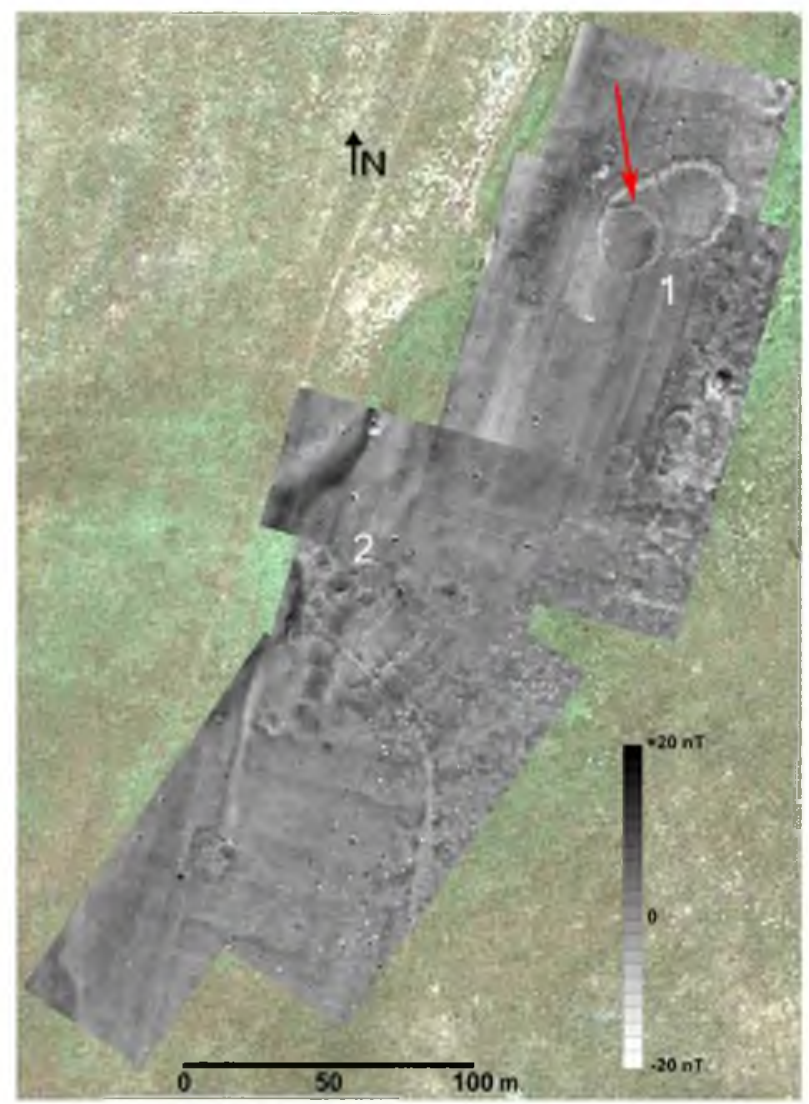

FIG URE 6 A large settlement on the Tarkhankut peninsula. A pair of corrals is at 1 , while several dwellings are located near 2 . Test pits in this area yielded artefacts of the Late Bronze Age and bone fragments from large and small cattle. The red arrow locates one excavation (Figure 7) where a detailed magnetic analysis was made. This is site $\mathrm{H} 8$ (see site 8 in Figure 1) [Colour figure can be viewed at wileyonlinelibrary.com]

about $0.4 \mathrm{~m}$; the width of the wall is about $2 \mathrm{~m}$. Based on the dimensions and depth of the wall in this excavation, a magnetic model of this feature was created.

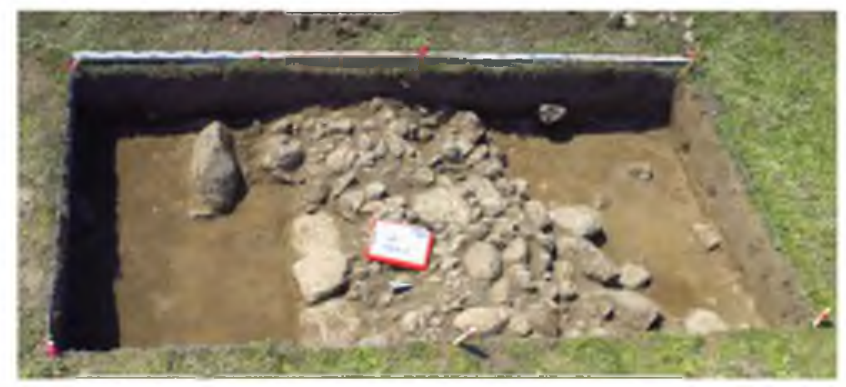

FIGURE 7 The stone wall of a corral at site H8. This excavation is $2 \mathrm{~m}$ by $4 \mathrm{~m}$ in size and the bare soil is at a depth of about $0.5 \mathrm{~m}$. The view in this photograph is toward the west and the photograph was taken by Ivan Litsuk [Colour figure can be viewed at wileyonlinelibrary.com] 
Figure 8 has several views of this analysis, which applied the Potent program. The excavation is outlined with a small black rectangle in Figure 8(a, b). The jagged blue curve in Figure $8(\mathrm{c})$ is a plot of the measurements that were made within the white rectangle in Figure 8(a). The wall is actually a cluster of stones, but it was approximated by a ridged box that is outlined with a thick red line. The calculated magnetic anomaly of this simple model is drawn as a smooth red curve in Figure $8(\mathrm{c})$, while the two-dimensional pattern of the calculation is plotted in Figure 8(b).

At this site, the magnetic susceptibility of limestone is around $0.015 \mathrm{ppt}$ and the soil at the depth of this wall has a susceptibility of $1.1 \mathrm{ppt}$. The magnetic contrast between the wall and the soil is the difference between their susceptibilities, which is $-1.1 \mathrm{ppt}$.
The calculated magnetic anomaly is similar to the measurements; most importantly, the lateral gradients of the measurements and the calculations are almost the same. The remanent magnetization of the soil was included in this calculation, and the $Q$ ratio is listed as 0.3 in Figure 8; this is the ratio of remanent to induced magnetization. This calculation assumes that the stone wall contains no soil. While there is soil within the wall, its effect is apparently balanced by the stone rubble that is outside the intact wall, but which is not included in the model. The calculation suggests that the stone wall that was unearthed in the excavations was the entire source of the magnetic anomaly.

Double pens sometimes have odd shapes. At settlement H2 (Figure 1, site 7) the southern corral has two equal parts, creating a

(a)

mage - Observed TM

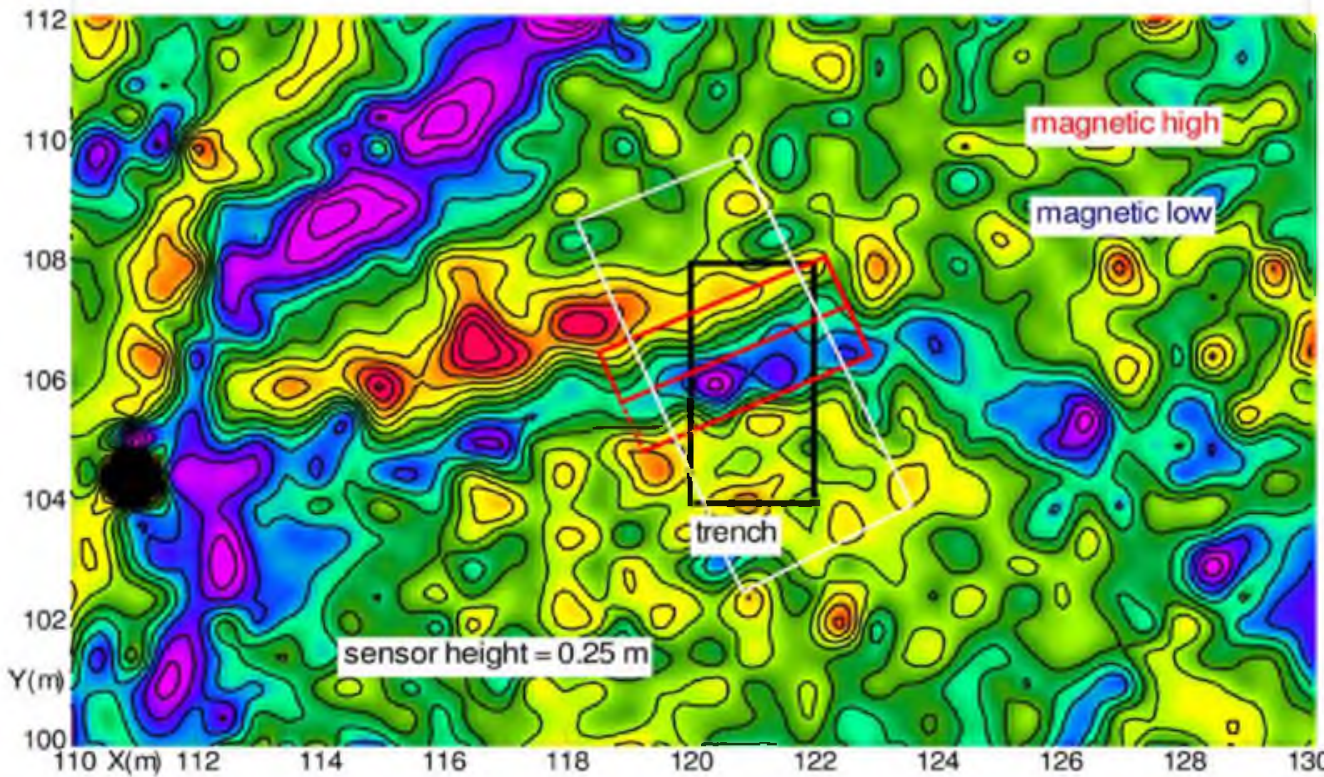

(b)

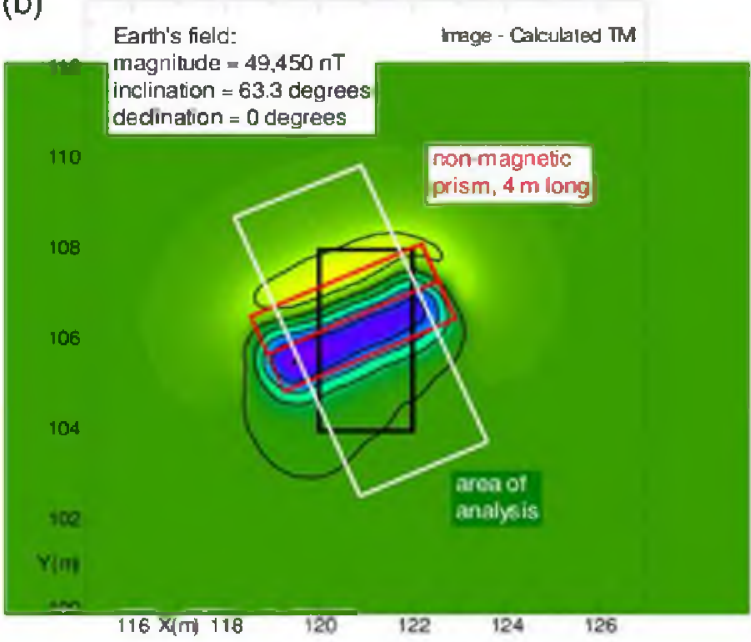

(c) 8

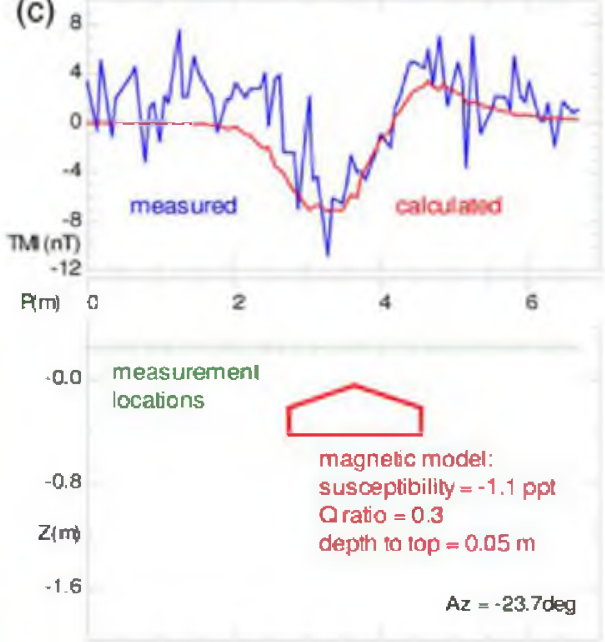

FIG URE 8 The magnetic model of part of the stone wall at site $\mathrm{H} 8$. (a) The measurements, (b) the calculated anomaly. The magnetic model is outlined with red, and it has the shape of a house with a sloping roof. Its calculated field is similar to the measurements. (c) View of the model, looking along its length. The parameters of the magnetic model have been determined from an excavation. Magnetic north is upwards in the figure [Colour figure can be viewed at wileyonlinelibrary.com] 


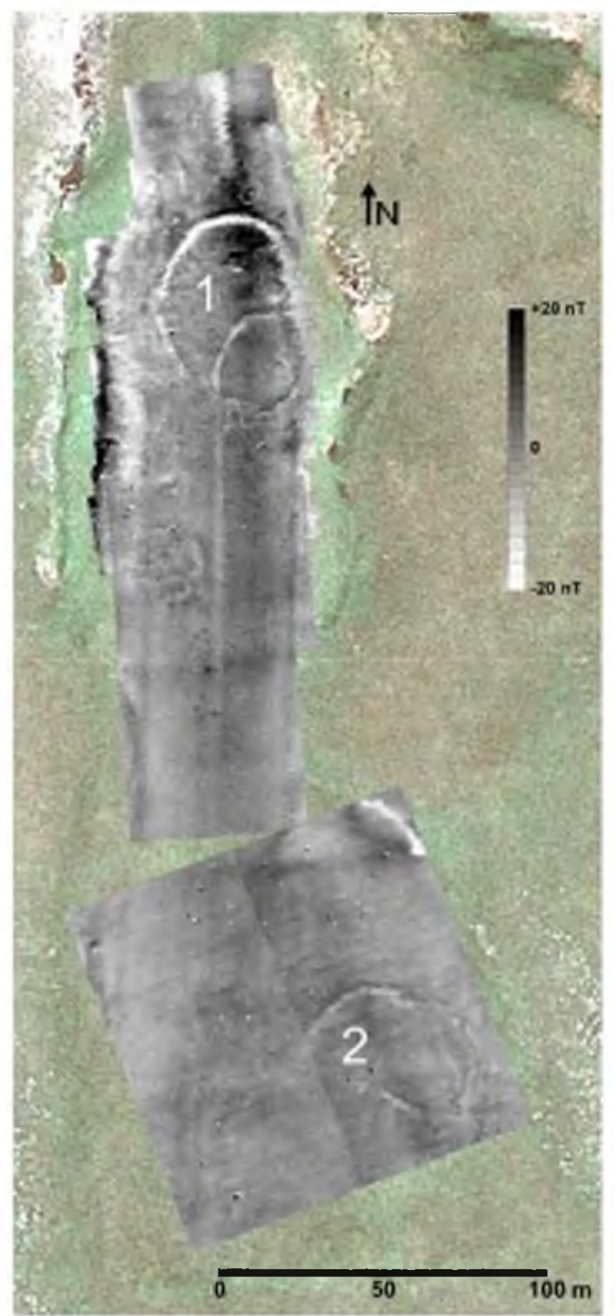

FIGURE 9 Two pairs of corrals at one site. These are marked with 1 and 2. This is site $H 2$, which is located near Lake Dzharylgach (see site 11 in Figure 1) [Colour figure can be viewed at wileyonlinelibrary. com]

shape like the letter B (Figure 9). Another example of a pen with an irregular shape is at site $\mathrm{H} 22 \mathrm{a}$ (Figure 1, site 14); Figure 10.

\section{2 | Settlements without corrals}

It is almost certain that some Bronze Age settlements did not have stone-walled corrals, for wide-area magnetic surveys have not revealed them. At some of these settlements, a ring of houses may have formed a corral for livestock. Perhaps some settlements kept their livestock in pens that were fenced with wood or reeds; these have left no trace, except perhaps for an area with high electrical conductivity or other indications of manure.

Bronze Age settlements with corrals have been found almost entirely near the Tarkhankut peninsula. Many other Bronze Age settlements have been discovered to the southeast, but no corrals have been found near them. These settlements are located in the watershed of Lake Sasyk-Sivash to the northeast of the city of Yevpatoria
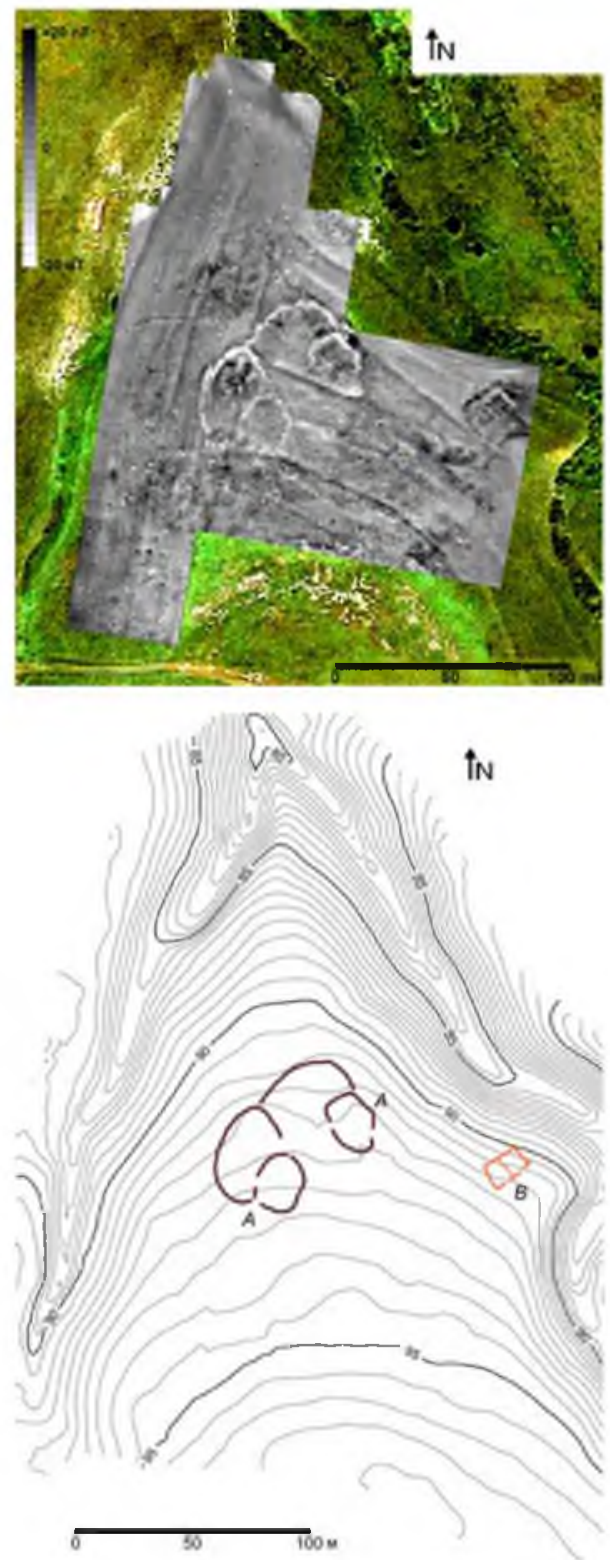

FIGURE 10 Settlement H22a. Again, there are two pairs of corrals. These are both marked $A$ in the topographic map, which shows how the corrals are located on a ridge between two valleys, while the likely dwelling (marked $B$ ) is at a lower elevation. The contour interval in the topo map is $0.05 \mathrm{~m}$. The grey-scale magnetic map reveals the corrals and the walls of the dwelling as white lines (magnetic lows). Excavations exposed one wall of a corral and also part of the dwelling at this site, which is located in the middle of the Tarkhankut peninsula (see site 14 in Figure 1) [Colour figure can be viewed at wileyonlinelibrary.com]

(Figure 1). This area also has branched ravines, and these extend far into the steppe. Numerous archaeological sites of the Late Bronze Age and Early Iron Age have recently been discovered here. Figure 11 shows semi-rectangular magnetic highs from pit houses at one site.

The settlement of Tyumen 3 was discovered on the northern shore of Lake Sasyk-Sivash along a ridge between two ravines (Figure 1, site 16). Magnetic surveys in an area of more than 16 ha 


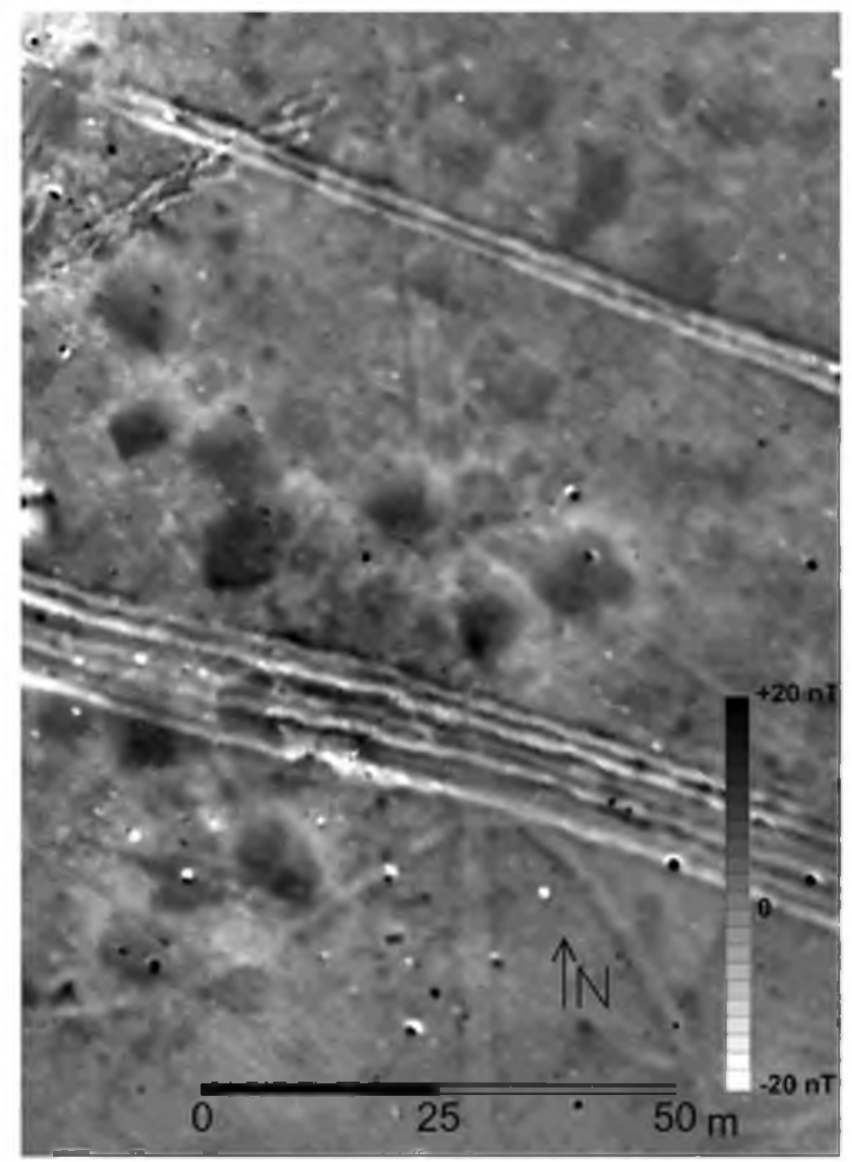

FIG URE 11 The magnetic map of a group of Late Bronze Age houses. Magnetic soil that fills the pits of the houses causes the dark grey patterns; these have a width of about $10 \mathrm{~m}$. There are more than two dozen of these features in this map. The ruts of modern dirt roads cause the linear anomalies. This site is Bagai 1 , which is on the north-western shore of Lake Sasyk-Sivash (see site 17 in Figure 1)

(Figure 12) revealed the plan of the settlement, which has at least 20 groups of houses, each consisting of two to three separate dwellings.

The anomalies are somewhat rectangular and they approximate the actual shape of the houses. The length or width of the dwellings varied from 2 to $10 \mathrm{~m}$. As seen in Figure 12, the line of the houses is an oval, measuring $300 \mathrm{~m} \times 200 \mathrm{~m}$. These houses might have been part of an enclosure for livestock, so that no stone-walled corral was needed.

An additional example of a settlement is at Tyumen 15, which is also located along the Tyumen ravine. Magnetic surveys found 32 positive anomalies that are approximately rectangular (Figure 13). No corral has been revealed yet by the magnetic survey at this site.

Magnetic and conductivity maps that were measured at Tyumen 15 found quite different patterns; see Figure 14. The difference between the maps is clarified in the middle panel of Figure 14; while this is simplified, and only locates the anomalous high readings, it does show that there was little correlation between the surveys. The magnetic survey clearly revealed several house pits as rather similar anomalies; however, the conductivity survey found strong anomalies

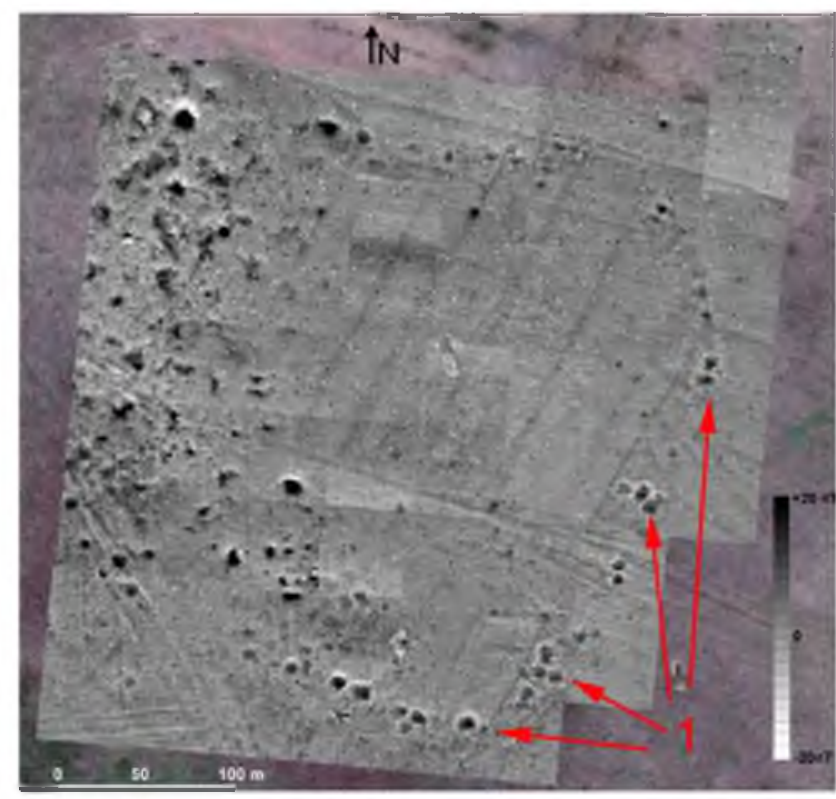

FIG URE 12 A ring of house pits at Tyumen 3. Several clusters of buildings that date to the Late Bronze Age are marked with red arrows at 1. No corral was found at this site. The edges of several plowed fields are visible on the magnetic map as dark grey lines (weak positive anomalies) that go toward the upper right. This settlement is on the northern shore of Lake Sasyk-Sivash (see site 16 in Figure 1) [Colour figure can be viewed at wileyonlinelibrary.com]

between those dwellings. The pair of surveys allows a greater distinction between the anomalies; for example, not only can magnetic highs and lows be contrasted, but also magnetic highs and conductivity lows, and so on. These additional contrasts will guide future excavations.

The conductivity survey indicated a background or nonanomalous value of $20 \mathrm{mS} / \mathrm{m}$ (which is a resistivity of $50 \mathrm{ohm}-\mathrm{m}$ ). The measurement of apparent conductivity rises to $50 \mathrm{mS} / \mathrm{m}$ near the middle of the survey area; the actual conductivity of the soil within this feature must be greater than that. That actual conductivity can be approximated by assuming a three-layer earth. The conductivity of the upper layer can be assumed to be $20 \mathrm{mS} / \mathrm{m}$, the background level that was measured. While the conductivity of the bottom layer is not known, it has been fixed at a value of $20 \mathrm{mS} / \mathrm{m}$ also. Calculations (McNeill, 1980) then suggest one possible model: A soil layer between a depth of 0.3 and $1.5 \mathrm{~m}$ could have a conductivity of $70 \mathrm{mS} / \mathrm{m}$ (14 ohm-m). This conductive layer could be natural clay; however, it is also possible that the high conductivity could be caused by a former animal pen that does not have a detectable fence. A similar high conductivity anomaly was revealed next to a Late Bronze Age dwelling at site 22a; this is located at B in Figure 10. A resistivity sounding over that anomaly found almost the same stratification as at Tyumen 15.

The pair of magnetic anomalies at the lower right corner of Figure 14 are analysed in Figure 15. While these features have not been excavated, Bronze Age house pits must cause these anomalies. The magnetic field of each house was approximated with a pair of 


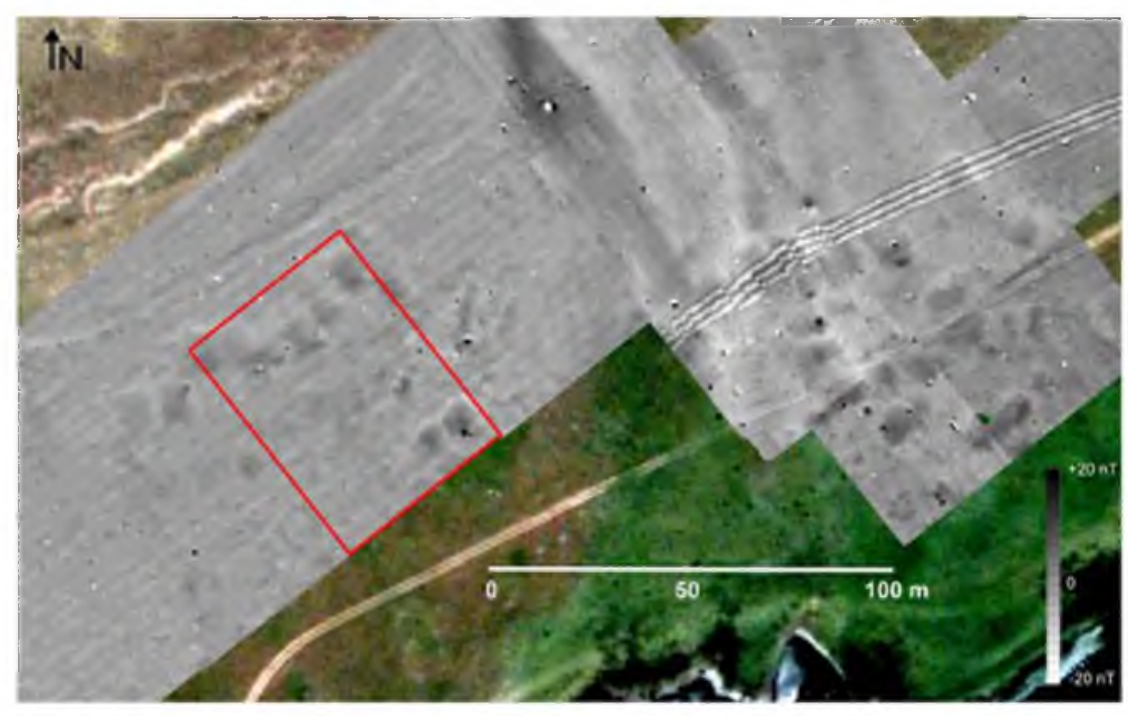

FIGURE 13 The settlement of Tyumen 15. Magnetic surveys revealed a group of positive anomalies (magnetic highs that are dark grey). Most of these are rather rectangular; negative anomalies or 'halos' can surround them. The red rectangle locates the enlargement in Figure 14. This site is on the north bank of the Tyumen balka (see site 15 in Figure 1) [Colour figure can be viewed at wileyonlinelibrary.com]

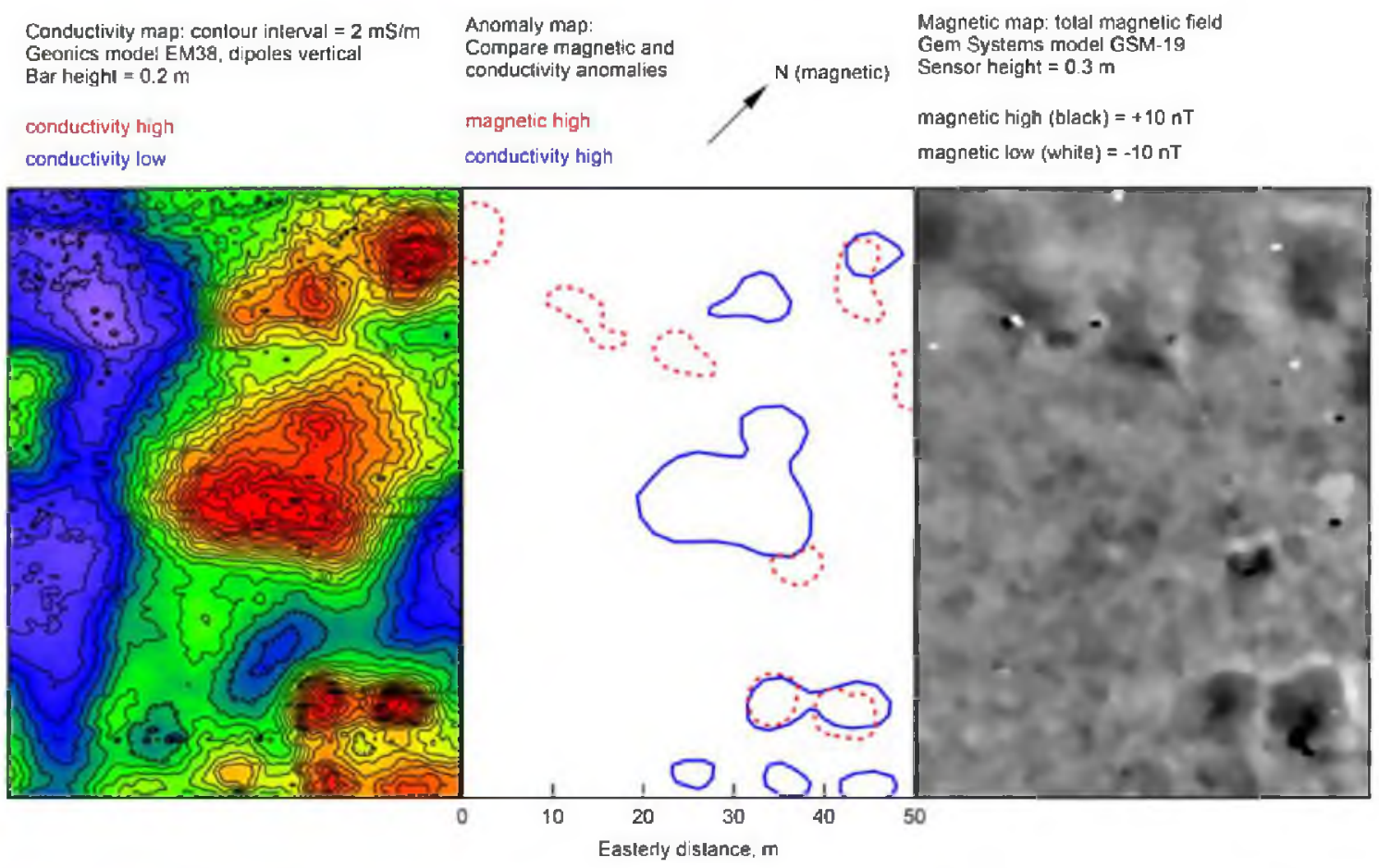

FIG URE 14 Magnetic and conductivity maps of a small part of the Tyumen 15 site. The central panel compares the major anomalies. Magnetic highs are approximated there with red dashed lines, while high conductivity areas are indicated with solid blue lines. The surveys agree at only about three anomalies [Colour figure can be viewed at wileyonlinelibrary.com]

rectangular boxes. The red boxes are models for the pits; these have a magnetic susceptibility of $2 \mathrm{ppt}$ greater than the surrounding soil. The blue boxes are models of likely fire hearths at the bottoms of each pit; these have a susceptibility that is 12 ppt greater than the soil in the pits. A non-magnetic band around each pit represents the stone walls that line each pit house. The calculations of these forward models are similar to the measurements, and this analysis suggests that the pits have a magnetic moment of $1.7 \mathrm{Am}^{2}$, while the fire hearths have a moment of $0.25 \mathrm{Am}^{2}$. Magnetic moment is a parameter that quantifies the amount of magnetic material in a body; unlike a description of an anomaly by its peak field in nanotesla, magnetic moment is independent of sensor height, feature depth, or the mode of measurement (total field or gradiometer). A better magnetic model will be created after the excavation of a pit house.

\section{7 | DISCUSSION}

Magnetic surveys have been excellent for detecting these stone enclosures; microbiological examination has provided good evidence 
(a)

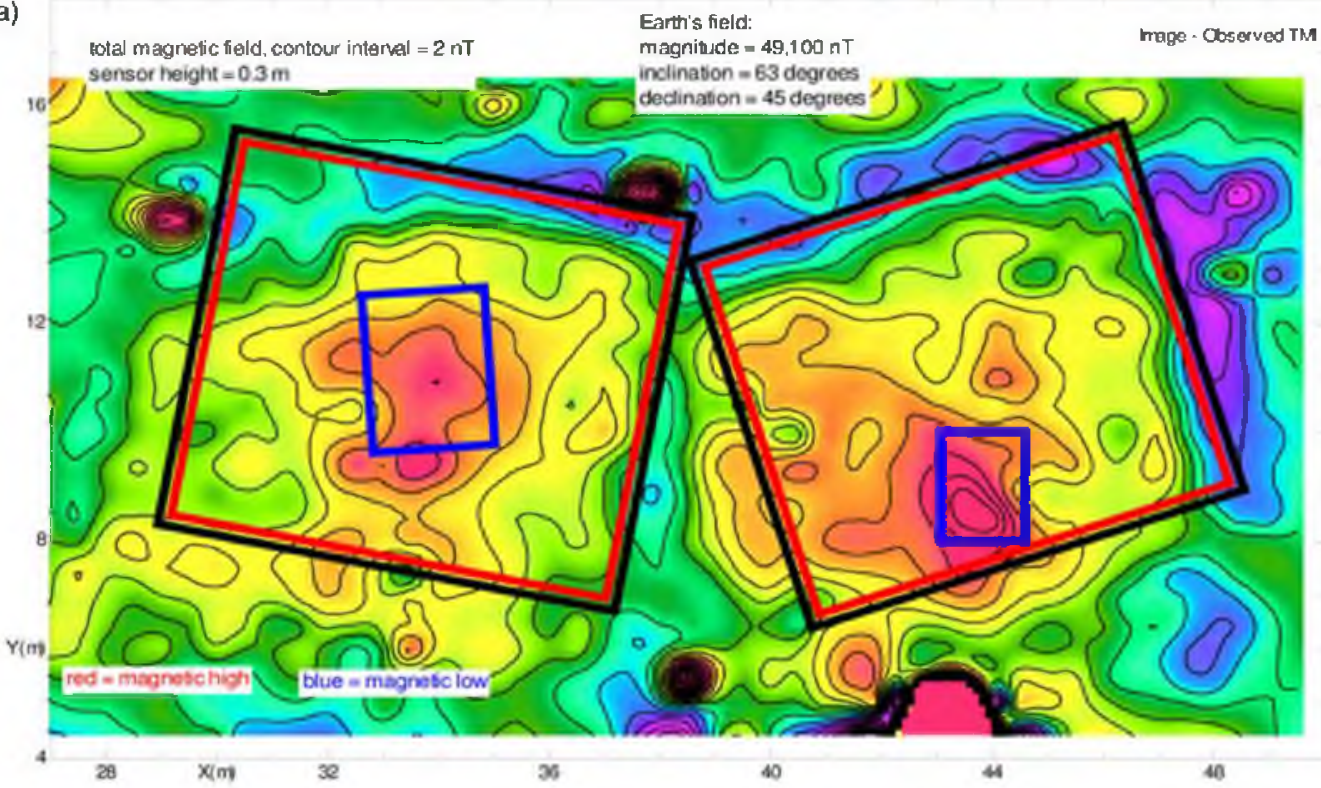

(b)

large red boxes : houge pits, thickness $-0.5 \mathrm{~m}$, depth $=0.5 \mathrm{~m}$, susceptibility $=2.3$ ppt huge - Calculated TM

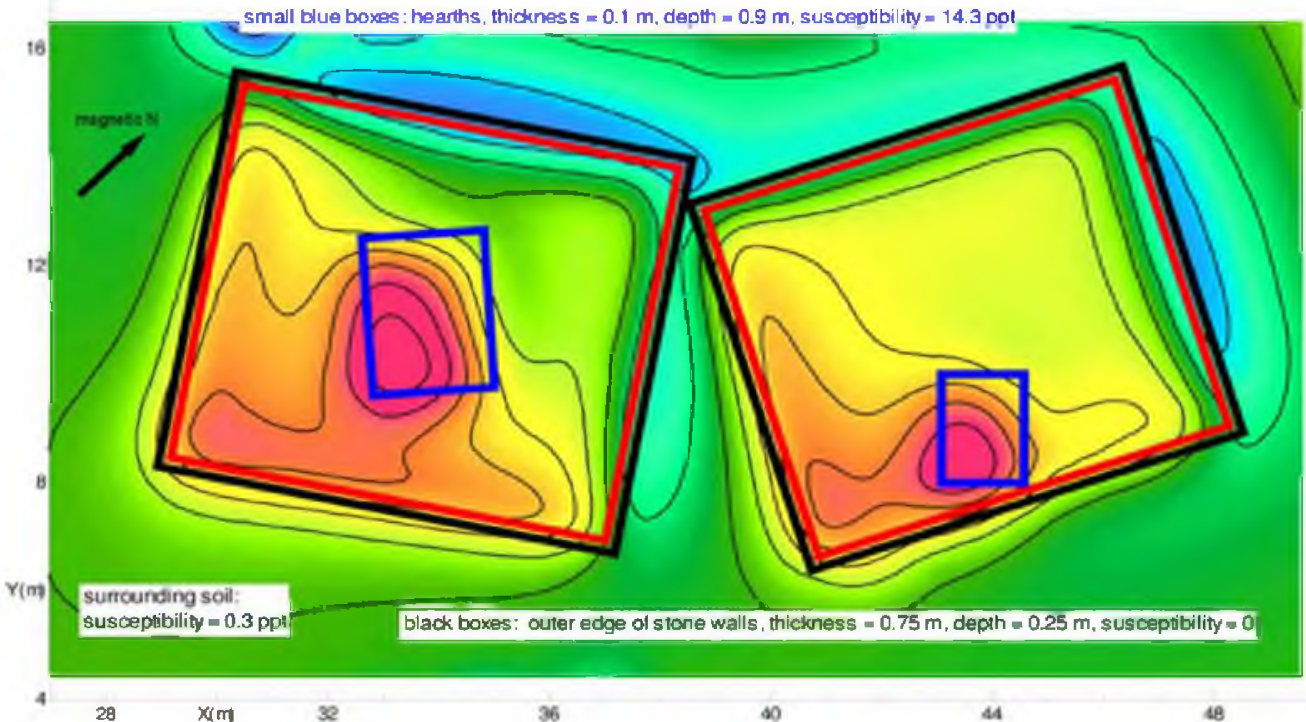

FIG URE 15 An analysis of two Bronze Age house pits. (a) Displays the magnetic measurements; distinctive lows (blue) are found to the north of the highs. (b) Reveals that the pits can be approximated with simple magnetic boxes. These are shown as coloured rectangles that are outlined black and red. The blue rectangles may locate hearths at the bottom of the pits [Colour figure can be viewed at wileyonlinelibrary.com]

that they are corrals. Other methods might have been applied to the search for corrals, such as mapping magnetic susceptibility or soil phosphate. Similarly, alternative techniques could have identified that the features are corrals, such as multi-element soil chemistry (Nielsen \& Kristiansen, 2014) or the detection of dung spherulites (Brochier, Villa, \& Giacomarra, 1992).

The soil within the corrals is reasonably more conductive than the surrounding soil; however, not enough measurements have been made to be certain of this. The soil within the corrals also appears to have a greater magnetic susceptibility than the soil outside; however, more measurements are needed to be certain. It is already clear that the magnetic maps do not show any distinctive difference between the inside of a corral as compared to outside, or between the two parts of a paired corral. While there may be some difference, the general variability within the magnetic maps prevents the detection of faint contrasts across the borders of the stone walls.

The stone walls create an irregular or granular anomaly whose amplitude changes significantly around the curve of the walls. This variability is mainly caused by changes in the fraction of stone in the soil, and by the depth and width of the stone wall. If the walls were constructed of squared blocks of stone, the anomalies would probably be more constant along the length of the walls. If the stone had significant remanent magnetization, the anomalies would change by a greater amount (Hesse, Barba, Link, \& Ortiz, 1997). Refilled ditches 
usually cause magnetic highs; since the magnetic topsoil that fills the ditches can be rather homogenous, the anomalies may change little along their lengths.

The soil contrasts at these corrals could be studied most economically with soil coring or augering, followed by geochemical and geophysical tests on the samples (Zhurbin \& Borisov, 2018). These procedures could also be applied to the high conductivity anomalies that have been located; these anomalies are broad and diffuse, and are not ideal for normal excavations.

Why are the corrals now buried and invisible at the surface? One possible explanation is that the fertile soil within the stone walls has allowed a thick growth of grass and small bushes over the millennia. This growth has reduced soil erosion and has also slowed the passing wind, allowing wind-blown soil to deposit within the vegetation. As a comparison, Iron Age settlements in Crimea never have the thick growth of vegetation on them, and the stones of Iron Age buildings are often visible at the surface.

The stone enclosures are animal pens; they indicate that the raising of livestock was important to the economy of the tribes in the Late Bronze Age. The separate parts of the corrals could have been helpful with herds of a mixed composition, allowing the separation of cows from sheep and goats. Separate pens could also have been necessary for milking livestock, or shearing sheep and goats.

Settlements of the Late Bronze Age on Tarkhankut are small, with the number of houses usually less than 12; these settlements have only one doubled corral. This indicates the social structure of the communities: The houses belonged to separate families while the entire community owned the herd. Settlements near Lake Sasyk-Sivash are much larger, for example the settlements of Tyumen 3 has more than 50 dwellings while the settlement of Tyumen 15 has 32 dwellings.

Paired corrals were never revealed by earlier surveys on the northern coast of the Black Sea and no examples are known from anywhere else. They had never been seen until 2017, when excavations for the new 'Tavrida' highway unearthed an example in eastern Crimea. During those large-area excavations, part of a double pen was uncovered, as well as several earth-dwellings whose pit walls were faced with flat stone slabs (Бейлин et al., 2018). The shape and age of these features are identical to those that had been discovered earlier with magnetic surveys in north-western Crimea.

It is possible that prior archaeologists have discovered parts of a double pen. However, the size of these enclosures is so great that is was impossible to understand them in small excavations. For this reason, no examples of these features have been found in the archaeological literature. Nevertheless, there are some ethnographic similarities.

Similar double corrals are found in the mountainous country of Pindhos in Greek Macedonia. Doubled and three-fold stone and wooden pens there are intended for milking sheep (Chang $\&$ Tourtellotte, 1993, 260, figure 6). Similar enclosures, with partitions, can also have served for shearing sheep.

The magnetic maps reveal what are logically called 'long fields' for they can extend for more than $100 \mathrm{~m}$; see Figure 3 in particular, but also Figures 10 and 11 . While these patterns are often visible in satellite photographs, the magnetic surveys reveal them as long and linear or curving magnetic anomalies. The predominant polarity of the magnetic anomalies alternates from one anomaly to the adjacent one. The distance from a linear high to a parallel low is usually about $25 \mathrm{~m}$ (it varies from 15 to $40 \mathrm{~m}$ ).

The origin of these patterns is reasonable: The anomalies mark the edges and the middles of plowed fields. Where adjacent lines of a field are plowed in the same direction, the soil is shifted slightly to the side, but its thickness remains the same. However, at the border between fields and along the midline of each field, the magnetic topsoil can become thicker or thinner. A greater thickness of the soil creates a magnetic high, or positive anomaly, while a reduced thickness causes a magnetic low.

These long fields are often found where settlements from the Late Bronze Age have been discovered. The overlapping of the corrals by the long fields indicates that the fields are more recent than the settlements; however, the age of the fields has not been determined. The long fields were certainly for growing grain or a similar crop, and the crop would grow best where the soil was fertile. This was just where the Late Bronze Age manure and organic matter was located. Therefore, the people who followed must have noted the fertile soil that was left by the Late Bronze Age civilization. These later people deliberately placed many of their fields where the soil was, and still is, very fertile.

\section{8 | CONCLUSIONS}

Magnetic surveys have been essential for the discovery of these archaeological features; surveys at 32 settlements have discovered 22 corrals that date to the Late Bronze Age in north-western Crimea. The typical diameter of these corrals is $40-50 \mathrm{~m}$ and the width of their walls is about $2 \mathrm{~m}$. Double corrals predominate; single pens have been found at only two settlements.

Since the magnetic surveys identified the unique shape of these corrals, small excavations were made at only four locations. Tests on excavated soil found high concentrations of thermophilic microorganisms inside one stone ring; this is excellent evidence that this was a corral for livestock, for these microorganisms are found where plant residues or animal dung have been heated by composting.

These corrals are probably a distinctive feature of the Late Bronze Age throughout Crimea, for they have been discovered over a wide area. Earthen dwellings, each about the same size and shape, accompany these corrals. These findings suggest the existence of a uniform archaeological culture and economy in the Late Bronze Age of Crimea. Kindred families inhabited the settlements here, jointly owning the source of their prosperity: Herds of a mixed composition.

While dwellings dating to the Late Bronze Age have been discovered in Crimea before, the stone-walled pens have not been found earlier; this is because of their large size. Even if they have been found in excavations, they could not be interpreted as corrals. Wide-area magnetic surveys have allowed the full size and unique shape of these 
features to be discovered. It is unusual when a geophysical survey reveals an archaeological feature that has never before been seen at the surface or in any excavation; however, this has happened here.

North-western Crimea is a palimpsest of farms, fields, settlements, and burials from many different periods. The archaeological sites in this area have an unusually good state of preservation, but it is challenging to distinguish the many different cultures that are found superimposed here.

\section{ACKNOWLEDGEMENTS}

The article by Chang and Tourtellotte (1993) was kindly pointed out to Smekalova in 2009 by Prof. Pia Guldager Bilde (Aarhus University). Alexei Gilevich translated and edited an initial version of the text of this article. Thanks to the following assistants for their help with geophysical and archaeological fieldwork: Andrei Chudin, Alexander Garipov, Alexei Senin, Sergei Fridrikhson, Andrei Gavrilyuk, Ivan Litsuk, Anna Antipenko, Alexei Devaev, Evgenia Davydova, Lev Leonov, and Ivan Zhivanyuk.

The authors appreciate the many improvements that were suggested by two anonymous reviewers; one of these reviewers was particularly helpful.

\section{DECLARATION OF INTEREST AND DATA AVAILABILITY}

All the authors declare that they have no conflict of interest.

The data of this geophysical survey are available from the authors.

\section{FUNDING INFORMATION}

Russian Foundation for Basic Research, project number 18-00-00563 K (18-00-00486).

\section{ORCID}

Tatiana Smekalova (1) https://orcid.org/0000-0001-5378-5372

Bruce Bevan D https://orcid.org/0000-0001-6334-5848

Fedor Lisetskii $\odot$ https://orcid.org/0000-0001-9019-4387

\section{REFERENCES}

Aspinall, A., Gaffney, C., \& Schmidt, A. (2008). Magnetometry for archaeologists. Plymouth, UK: AltaMira Press.

Becker, H., \& Fassbinder, J.W.E. (2001) Magnetic prospecting in archaeological sites. Monuments and Sites, VI, International Council on Monuments and Sites, Paris

Bevan, B. W. (1996). Geophysical exploration in the U.S. national parks. Northeast Historical Archaeology, 25, 69-84.

Bevan, B.W. (2016) Forward magnetic models: Creation and calculation, Geosight report, Weems, VA, USA. https://www.academia.edu/ 26462280

Brochier, J. E., Villa, P., \& Giacomarra, M. (1992). Shepherds and sediments: Geo-ethnoarchaeology of pastoral sites. Journal of Anthropological Archaeology, 11, 47-102. 10.1016/0278-4165(92)90010-9

Chadwick, A. (2013). Some fishy things about scales: Macro- and microapproaches to later prehistoric and Romano-British field systems. Landscape, 14(1), 13-32. 10.1179/1466203513Z.0000000002

Chang, C., \& Tourtellotte, P. A. (1993). Ethnoarchaeological survey of pastoral transhumance sites in the Grevena region, Greece. Journal of Field Archaeology, 20, 249-264. 10.1179/009346993791549192
Chernysheva, E., Korobov, D., \& Borisov, A. (2017). Thermophilic microorganisms in arable land around medieval archaeological sites in Northern Caucasus, Russia: Novel evidence of past manuring practices. Geoarchaeology, 32(4), 494-501. 10.1002/gea.21613

Chernysheva, E., Korobov, D., Khomutova, T., \& Borisov, A. (2015). Urease activity in cultural layers at archaeological sites. Journal of Archaeological Science, 57, 24-31. https://doi.org/10.1016/j.jas.2015.01.022

Clay, R. (2000). Conductivity (EM) survey: A survival manual. Lexington, KY: Cultural Resource Analysts, Inc.

Davis, D., Prieto, A., Lovén, B., \& Christiensen, K. (2003) Report on four gradiometer surveys in the chora of Metaponto. The Institute of Classical Archaeology, University of Texas at Austin, Austin, TX.

De Vore, S., (2002) Magnetic gradient survey of Seminoe's Fort on the Tom Sun Ranch along the Oregon and California National Historic Trails, Natrona County, Wyoming, Midwest Archeological Center Technical Report, No. 77. Midwest Archeological Center, National Park Service, Lincoln, NE. doi: 10.6067/XCV89Z94NN

Fischl, K., Kienlin, T.L., \& Pusztai, T. (2016) Bronze age settlement research in the southern Borsod region, Hungarian Archaeology e-journal. http://files.archaeolingua.hu/2016NY/Fischl_Kienlin_Pusztai_ E16NY.pdf

Furmanek, M., Mackiewicz, M., Myślecki, B., \& Wroniecki, P. (2015). Uncovering Neolithic and Early Bronze Age landscapes: New data from southwestern Poland. Archaeologia Polona, 53, 69-84.

Hesse, A., Barba, L., Link, K., \& Ortiz, A. (1997). A magnetic and electrical study of archaeological structures at Loma Alta, Michoacan, Mexico. Archaeological Prospection, 4, 53-67.

Lane, M. F., Horsley, T. J., Charami, A., \& Bittner, W. S. (2016). Archaeological geophysics of a Bronze Age agricultural landscape: the AROURA Project, central mainland Greece. Journal of Field Archaeology, 41(3), 271-296. https://doi.org/10.1080/08869634.2016.1176375

Lindsay, I., Leon, J., Smith, A. T., \& Wiktorowicz, C. (2014). Geophysical survey at Late Bronze Age fortresses: comparing methods in the diverse geological contexts of Armenia. Antiquity, 88, 578-595. https://doi.org/10.1017/S0003598X0010119X

Lindsay, I., Smith, A. T., \& Badalyan, R. (2010). Magnetic survey in the investigation of sociopolitical change at a Late Bronze Age fortress settlement in northwestern Armenia. Archaeological Prospection, 17(1), 15-17. https://doi.org/10.1002/arp.369

Lisetskii, F. N., Smekalova, T. N., \& Marinina, O. A. (2016). Biogeochemical features of fallow lands in the steppe zone. Contemporary Problems of Ecology, $\quad 9(3), \quad 366-375 . \quad \mathrm{https} / /$ doi.org/10.1134/ S1995425516030094

Martyshko, P.S., Noskewich, V.V., Fedorova, N.V., \& Muraviev, L.A. (2010) Geophysical researches on excavations of the Bronze Age fortified settlement in southern Ural mountains, Near Surface 2010 - 16th European Meeting of Environmental and Engineering Geophysics, Zurich, Switzerland. https://doi.org/10.3997/2214-4609.20144875

Matney, T., \& Algaze, G. (1995). Urban development at mid-late Early Bronze Age Titriş Höyük in southeastern Anatolia. Bulletin of the American Schools of Oriental Research, BASOR, 299(300), 33-52. https://doi.org/ 10.2307/1357344

McNeill, J.D. (1980) Electromagnetic terrain conductivity measurement at low induction numbers. Technical Note TS-6. Geonics Limited, Mississauga, ON. http://www.geonics.com/pdfs/technicalnotes/tn6.pdf

Nielsen, N. H., \& Kristiansen, S. (2014). Identifying ancient manuring: traditional phosphate vs. multi-element analysis of archaeological soil. Journal of Archaeological Science, 42, 390-398. https://doi.org/10.1016/j. jas.2013.11.013

Nolan, K. C. (2014). Prospecting for prehistoric gardens: Results of a pilot study. Archaeological Prospection, 21, 147-154. https://doi.org/10. 1002/arp.1465

Olsen, S., Bradley, B., Maki, D., \& Outram, A. (2006). Community organisation among copper age sedentary horse pastoralists of Kazakhstan. In D. L. Peterson, L. M. Popova, \& A. T. Smith (Eds.), Beyond the steppe 
and the sown. Proceedings of the 2002 University of Chicago Conference on Eurasian Archaeology. (pp. 89-111). Leidenchapter 4: Brill.

Reinhold, S., Korobov, D.S., \& Belinskij, A.B. (2017) Landschaftsarchäologie im Nordkaukasus. Studien zu einer neu entdeckten bronzezeitlichen Kulturlandschaft im Hochgebirge des Nordkaukasus (Archäologie in Eurasien, Bd. 38). Bonn.

Smekalova, T. N., Bevan, B. W., Chudin, A. V., \& Garipov, A. S. (2016). The discovery of an ancient Greek vineyard. Archaeological Prospection, 23(1), 15-26. https://doi.org/10.1002/arp.1517

Smekalova, T. N., Yatsishina, E. B., Garipov, A. S., Pasumanskii, A. E., Ketsko, R. S., \& Chudin, A. V. (2016). Natural science methods in field archaeology, with the case study of Crimea. Crystallography Reports, 61(4), 533-542. https://doi.org/10.1134/S1063774516030251

Wiewel, A. S., \& Kvamme, K. L. (2014). Magnetic investigations of nomadic group encampments at Fort Clark State Historic Site, North Dakota. Plains Anthropologist, 59, 261-278. https://doi.org/10.1179/ 2052546X14Y.0000000010

Zhurbin, I., \& Borisov, A. (2018). Capabilities of consistent application of geophysical and geochemical surveys of medieval settlements destroyed by plowing. Archaeological Prospection, 25, 219-230. 10.1002/ arp.1704
Бейлин, Д.В., Кислый, А.Е., Михайлов, А.М., Рогудеев, В.В., Шарапа, А.В., \& Юрочкин, В.Ю (2018). Раскопки поселения эпохи бронзы Госпиталь II в г. Керчи (предварительное сообщение). Древности Боспора. Вып. 23. Москва, 2018. С. 9-35.

Колотухин, В. А. (2003). Поздний бронзовый век Крьма. Киев: Стилос.

Смекалова, Т. Н. (2010). Памятники эпохи бронзы и раннего железного века на полуострове Тарханкут: Каталог. Доля: Материалы к археологической карте Крыма. Выпуск ІІ. Симферополь.

Смекалова, Т.Н., и Кутайсов, В.А. (2017) Археологический атлас СевероЗападного Крыма. Поздний бронзовый век. Ранний железный век. Античность. Санкт-Петербург, "Алетейя". 2017.

How to cite this article: Smekalova T, Bevan B, Kashuba M, Lisetskii F, Borisov A, Kashirskaya N. Magnetic surveys locate Late Bronze Age corrals. Archaeological Prospection. 2020; 1-14. https://doi.org/10.1002/arp.1789 